\title{
Article \\ Small Differences in Vitamin D Levels between Male Cardiac Patients in Different Stages of Coronary Artery Disease
}

\author{
Ewelina A. Dziedzic ${ }^{1, *(\mathbb{D})}$, William B. Grant ${ }^{2} \mathbb{D}$, Izabela Sowińska ${ }^{3} \mathbb{D}$, Marek Dąbrowski ${ }^{4}$ \\ and Piotr Jankowski 5,6 iD \\ 1 Medical Faculty, Lazarski University in Warsaw, 02-662 Warsaw, Poland \\ 2 Sunlight, Nutrition, and Health Research Center, P.O. Box 641603, San Francisco, CA 94164-1603, USA \\ wbgrant@infionline.net \\ 3 Medical Faculty, Medical University of Warsaw, 02-091 Warsaw, Poland; sowinska.izabela@gmail.com \\ 4 Department of Cardiology, Bielanski Hospital, 01-809 Warsaw, Poland; mardab@wp.pl \\ 5 Department of Internal Medicine and Geriatric Cardiology, Centre of Postgraduate Medical Education, \\ 01-813 Warsaw, Poland; piotrjankowski@interia.pl \\ 6 Institute of Cardiology, Jagiellonian University Medical College, 31-008 Krakow, Poland \\ * Correspondence: ewelinadziedzic82@gmail.com; Tel.: +48-792207779
}

check for updates

Citation: Dziedzic, E.A.; Grant, W.B.; Sowińska, I.; Dąbrowski, M.; Jankowski, P. Small Differences in Vitamin D Levels between Male Cardiac Patients in Different Stages of Coronary Artery Disease. J. Clin. Med. 2022, 11, 779. https://doi.org/ $10.3390 / \mathrm{jcm} 11030779$

Academic Editor: Anna

Kabłak-Ziembicka

Received: 30 December 2021

Accepted: 28 January 2022

Published: 31 January 2022

Publisher's Note: MDPI stays neutral with regard to jurisdictional claims in published maps and institutional affiliations.

Copyright: (C) 2022 by the authors. Licensee MDPI, Basel, Switzerland. This article is an open access article distributed under the terms and conditions of the Creative Commons Attribution (CC BY) license (https:// creativecommons.org/licenses/by/ $4.0 /$ )

\begin{abstract}
Cardiovascular diseases are the main cause of mortality in males older than 65 years of age. The prevalent vitamin D deficiency in the worldwide population may have multiple effects on the cardiovascular system. This study sought to determine the association between serum levels of 25-hydroxyvitamin D $(25(\mathrm{OH}) \mathrm{D})$ and the stage of coronary artery disease (CAD) in Polish male subjects. Additionally, subjects with a history of myocardial infarction (MI) were analyzed for potential differences in $25(\mathrm{OH}) \mathrm{D}$ levels in comparison with those diagnosed with stable CAD. The study was conducted prospectively in a group of 669 male patients subjected to coronarography examination. CAD stage was defined using the Coronary Artery Surgery Study Score. Patients without significant coronary lesions had significantly higher 25(OH)D levels than patients with single-, double-, or triple-vessel disease (median, 17 vs. $15 \mathrm{ng} / \mathrm{mL} ; p<0.01$ ). Significantly lower levels of $25(\mathrm{OH}) \mathrm{D}$ were apparent when MI was identified as the cause of the then-current hospitalization in comparison with stable CAD, as well as in patients with a history of MI; all of these cases had lower levels of $25(\mathrm{OH}) \mathrm{D}$ in comparison with patients with no such history. Male patients with single-, double-, or triple-vessel CAD, acute coronary syndrome, or a history of MI presented lower serum $25(\mathrm{OH}) \mathrm{D}$.
\end{abstract}

Keywords: vitamin D; coronary artery disease; myocardial infarction; males; Coronary Artery Surgery Study Score

\section{Introduction}

The aging of the worldwide population is being observed in recent decades. Consequently, the subpopulation of male individuals older than 65 years in Poland has gradually increased [1-4]. In this group of patients, cardiovascular diseases account for more than half of all deaths [5]. Despite the observed improvement concerning mortality rates, a large difference between the average male and female lifespans persisted (73 and 81 years, respectively) [5]. Elderly men should be considered a unique group of patients liable to major cardiovascular events. Considering exceedingly high rates of the risk of death, cardiovascular diseases (CVDs) continue to prompt the need for the relentless investigation of their risk factors and new therapies [6]. As a result of advancements in treatment, including non-pharmacological prevention, the risk of death from CVDs has dropped by $20 \%$ over the last few decades [7]. Despite these improvements, CVD remains responsible for about 18 billion deaths per year, the majority of which are a consequence of myocardial infarction or stroke [8]. Appropriate physical activity and dietary interventions both reduce the 
cardiovascular risk $[9,10]$ and affect the level of 25-hydroxyvitamin D. Notably, calcitriol deficiency is identified as one of the new cardiovascular disease risk factors and has been proven to be prevalent in human populations worldwide [11-13].

The discovery of the biological mechanisms underlying vitamin D effects justifies studies of the association between its deficiency and the risk of cardiovascular diseases. The 1,25-dihydroxyvitamin D (calcitriol) receptor is present in numerous cells of the cardiovascular system [14]. Studies conducted on an animal model have shown an adverse effect of vitamin D deficiency on the functions of endothelial cells, vascular smooth muscle, and cardiomyocytes [14]. Due to the presence of the enzyme 1- $\alpha$ hydroxylase, these cells are capable of autocrine calcitriol synthesis $[15,16]$. This hormone is a negative regulator of the axis of the renin-angiotensin-aldosterone system, the increased activity of which leads to the development of arterial hypertension and myocardial hypertrophy [17-19]. The relationship between calcitriol deficiency and individual stages of plaque formation and destabilization, as well as documented risk factors for coronary artery disease, has been documented $[13,20]$.

To date, the results of studies do not offer an explicit agreement on how vitamin D affects the cardiovascular system [21]. However, some reports suggest that $25(\mathrm{OH}) \mathrm{D}$ levels below the reference range may increase the risk of CVD [21], whereas optimum levels may exert a protective effect on both musculoskeletal and cardiovascular systems [21-23]. The main objective of this study was to assess the potential association between serum $25(\mathrm{OH}) \mathrm{D}$ levels and the stage of coronary artery disease (CAD) in Polish males.

\section{Materials and Methods}

\subsection{Population}

This study is part of a research project focused on the relationship between the level of vitamin $\mathrm{D}$ and the severity of coronary artery atherosclerosis in Polish cardiac patients. Results of the analysis of this association among 637 patients are presented in previously published articles, in which details of the study population and measurements (diabetes diagnosis, acute coronary syndrome (ACS) diagnosis, interview questionnaire, body mass index (BMI), concentration of total cholesterol (TC) and/or triglycerides (TG), systolic and diastolic blood pressure, coronary angiography, and total $25(\mathrm{OH}) \mathrm{D}$ in participant serum and plasma) were described [24-26]. Abnormal serum levels of phosphate, calcium and parathyroid hormone (PTH) treatments, or supplementation containing vitamin D or calcium served as exclusion criteria. Patients with stages III-V chronic kidney disease, active malignancy, and elevated inflammatory markers or fever were also excluded from the study. New patients were continuously examined, and final pooled data of Polish patients hospitalized in the Cardiology Department who underwent diagnostic catheter angiography for the evaluation of coronary artery disease in the years 2013 to 2017 were presented in the most previous study [27]. This study presents data for male patients.

The serum level of 25(OH)D was determined with the Vitamin D total assay by Roche Diagnostics, certified by VDSP. The Roche Diagnostics Vitamin D total assay is a competitive electrochemiluminescence protein-binding assay intended for the quantitative determination of the total $25-\mathrm{OH}$ vitamin $\mathrm{D}$ in human serum and plasma. The assay utilizes a vitamin-D-binding protein (VDBP) as the capture protein, which binds to both 25-OH D3 and 25-OH D2 [28].

The status of vitamin D levels was classified according to the Endocrine Society Clinical Practice Guidelines for Vitamin D Deficiency [29]: 25(OH)D level $<10 \mathrm{ng} / \mathrm{mL}$ was considered as a severe deficiency; $\geq 10$ to $<20 \mathrm{ng} / \mathrm{mL}$ as a moderate deficiency; $\geq 20$ to $<30 \mathrm{ng} / \mathrm{mL}$ as a mild deficiency; $\geq 30 \mathrm{ng} / \mathrm{mL}$ as optimal.

Coronary atherosclerosis was assessed by Coronary Artery Surgery Study Score (CASSS) according to the following rules [30]. Stenosis $\geq 50 \%$ of the left main coronary artery (LMCA) was scored at 2 points. Stenosis $>70 \%$ in any of the large epicardial coronary arteries (anterior descending branch, LAD; circumflex branch, LCx; right coronary artery, 
RCA) was scored at 1 point. The sum of all points equaled the score, which may indicate, respectively a one-, two-, or three-vessel CAD [30].

The study project was approved by the University Bioethical Committee (KB/124/2014) and followed the rules and principles of the Helsinki Declaration.

\subsection{Statistics}

The Shapiro-Wilk test was used to evaluate the normal distribution of data. The Poisson regression analysis was used to assess the relationship between 25(OH)D levels and selected variables. To compare the results of continuous variables between the two groups, the Mann-Whitney test or $t$-test was used. For comparisons of three or more independent groups, the Kruskal-Wallis test or one-way analysis of variance were used, depending on the presence of a Gaussian distribution (Shapiro-Wilk normality test). Pearson's chisquared test or Fisher's exact test was used to determine differences between prevalence in selected groups. Statistical analyses were performed with a significance level of $5 \%$ ( $p$ value $<0.05)$. The statistical analysis was carried out with STATISTICA 12.5 software.

\section{Results}

\subsection{Characteristics of the Study Group}

The study was conducted on 1345 patients admitted to the Department of Cardiology in the Bielanski Hospital in Warsaw (Poland) for coronarographic examination as a result of suspected CAD as identified in an outpatient setting. Final statistical analysis was carried out in 1043 patients (669 males, 374 females). The data of 302 subjects were excluded, as they met the study exclusion criteria (for details, see [27]).

\subsection{Comparisons between Female and Male Subpopulations}

Statistically significant differences were observed between females and males with regard to age, total cholesterol, high-density lipoprotein (HDL) cholesterol, and low-density lipoprotein (LDL) cholesterol levels. Statistically significant disproportions were observed between the female and male subpopulations with regard to smoking status, history of myocardial infarction, and the number of arteries presenting with significant stenosis (Table 1).

Table 1. Results between female and male subpopulations.

\begin{tabular}{|c|c|c|c|}
\hline Variable & Females & Males & $p$ \\
\hline$N$ & 374 & 669 & $\mathrm{~N} / \mathrm{A}$ \\
\hline Age (years) & $70 \pm 11$ & $65 \pm 11$ & $<0.001$ \\
\hline Body mass index $\left(\mathrm{kg} / \mathrm{m}^{2}\right)$ & $28 \pm 5$ & $28 \pm 5$ & 0.75 \\
\hline Body mass index class $(1 / 2 / 3)^{+}$ & $100 / 120 / 131$ & $156 / 274 / 197$ & $<0.05$ \\
\hline Diabetes (No/Yes/Prediabetes) & $242 / 120 / 12$ & $418 / 225 / 26$ & 0.72 \\
\hline Total cholesterol (mg/Dl) & $189 \pm 49$ & $172 \pm 46$ & $<0.001$ \\
\hline High-density lipoprotein (mg/dL) & $55 \pm 16$ & $46 \pm 14$ & $<0.001$ \\
\hline Low-density lipoprotein (mg/dL) & $108 \pm 44$ & $100 \pm 41$ & $<0.01$ \\
\hline Triglycerides (mg/dL) & $129 \pm 57$ & $130 \pm 74$ & 0.82 \\
\hline Hyperlipidemia (No/Yes) & $131 / 218$ & $265 / 348$ & 0.08 \\
\hline Hypertension (No/Yes) & $57 / 317$ & $124 / 545$ & 0.18 \\
\hline Smoking (No/Yes/Ex) & $272 / 72 / 30$ & $371 / 221 / 77$ & $<0.001$ \\
\hline History of myocardial infarction (No/Yes) & $254 / 120$ & $389 / 280$ & $<0.01$ \\
\hline Cause of hospitalization $(0 / 1) \ddagger$ & $232 / 141$ & $389 / 277$ & 0.23 \\
\hline Coronary Artery Surgery Study Score $(0 / 1 / 2 / 3)$ & $142 / 96 / 74 / 62$ & $126 / 180 / 208 / 155$ & $<0.001$ \\
\hline
\end{tabular}


Table 1. Cont.

\begin{tabular}{cccc}
\hline Variable & Females & Males & $p$ \\
\hline Level of 25-hydroxyvitamin D (ng/mL (range)) & $14(4-55)$ & $16(4-48)$ & 0.07 \\
\hline 25(OH)D level (1/2/3/4) ${ }^{* *}$ & $101 / 168 / 76 / 29$ & $128 / 357 / 149 / 35$ & $<0.01$ \\
\hline Season (October-April/May-September) & $291 / 83$ & $494 / 175$ & 0.16 \\
\hline
\end{tabular}

25(OH)D = 25-hydroxyvitamin D; BMI, body mass index; CASSS, Coronary Artery Surgery Study Score; HDL, high-density lipoprotein; LDL, low-density lipoprotein. ${ }^{\dagger}$ BMI class 1, <25; class 2, 25-30; class 3, >30; ${ }^{\ddagger} 0$, stable coronary artery disease; 1 , myocardial infarction; ${ }^{* *} 1$ : $<10 \mathrm{ng} / \mathrm{mL}$ severe deficiency, $2: \geq 10$ to $<20 \mathrm{ng} / \mathrm{mL}$ moderate deficiency, $3: \geq 20$ to $<30 \mathrm{ng} / \mathrm{mL}$ mild deficiency, $4: \geq 30 \mathrm{ng} / \mathrm{mL}$ optimal.

Statistically significant differences were observed between females and males with regard to age, total cholesterol, high-density lipoprotein (HDL) cholesterol, and low-density lipoprotein (LDL) cholesterol levels. Statistically significant disproportions were observed between the female and male subpopulations with regard to smoking status, history of myocardial infarction, and the number of arteries presenting with significant stenosis.

3.3. Analysis of Male Subpopulation, Correlation between 25(OH)D Levels or Other Parameters, and the CASSS Stage of Coronary Artery Disease in Male Subpopulation

Among male patients divided into individual CASSS severity groups (Table 2), analysis of variance revealed statistically significant differences in age, total cholesterol levels, HDL cholesterol levels, and LDL cholesterol levels.

Table 2. Characteristics of the examined group divided according to degree of coronary atherosclerosis (the Coronary Artery Surgery Study Score (CASSS)) into four subgroups.

\begin{tabular}{|c|c|c|c|c|c|}
\hline Variable & CASSS 0 & CASSS 1 & CASSS 2 & CASSS 3 & $p$ \\
\hline$N$ & 126 & 180 & 208 & 155 & \\
\hline Age (years) & $64 \pm 11$ & $64 \pm 12$ & $64 \pm 10$ & $68 \pm 10$ & $<0.001$ \\
\hline Body mass index $\left(\mathrm{kg} / \mathrm{m}^{2}\right)$ & $29 \pm 6$ & $28 \pm 5$ & $28 \pm 5$ & $28 \pm 5$ & 0.07 \\
\hline Body mass index class $(1 / 2 / 3)^{\dagger}$ & $30 / 45 / 47$ & $38 / 71 / 53$ & $49 / 93 / 55$ & $39 / 65 / 42$ & 0.50 \\
\hline Diabetes (No/Yes/Prediabetes) & $88 / 34 / 4$ & $122 / 52 / 6$ & $123 / 73 / 12$ & $85 / 66 / 4$ & $<0.05$ \\
\hline Total cholesterol (mg/dL) & $180 \pm 45$ & $176 \pm 44$ & $171 \pm 49$ & $163 \pm 45$ & $<0.05$ \\
\hline High-density lipoprotein (mg/dL) & $52 \pm 18$ & $46 \pm 13$ & $46 \pm 13$ & $43 \pm 12$ & $<0.001$ \\
\hline Low-density lipoprotein (mg/dL) & $104 \pm 38$ & $105 \pm 40$ & $100 \pm 43$ & $92 \pm 39$ & $<0.05$ \\
\hline Triglycerides (mg/dL) & $124 \pm 68$ & $127 \pm 66$ & $130 \pm 68$ & $137 \pm 93$ & 0.54 \\
\hline Hyperlipidemia (No/Yes) & $43 / 66$ & $61 / 107$ & $90 / 103$ & $71 / 71$ & 0.07 \\
\hline Hypertension (No/Yes) & $34 / 92$ & $36 / 144$ & $29 / 179$ & $25 / 130$ & $<0.05$ \\
\hline Smoking (No/Yes/Ex) & $88 / 26 / 12$ & $90 / 74 / 16$ & $104 / 72 / 32$ & $89 / 49 / 17$ & $<0.01$ \\
\hline History of myocardial infarction (No/Yes) & $115 / 11$ & $112 / 68$ & $96 / 112$ & $66 / 89$ & $<0.001$ \\
\hline Cause of hospitalization $(0 / 1) \ddagger$ & $113 / 13$ & $86 / 93$ & $115 / 91$ & $75 / 80$ & $<0.001$ \\
\hline $\begin{array}{l}\text { Level of 25-hydroksyvitamin } \\
\text { D (ng/mL (range)) }\end{array}$ & $17(5-47)$ & $15(4-48)$ & $15(4-37)$ & $15(4-43)$ & 0.05 \\
\hline $25(\mathrm{OH}) \mathrm{D}$ level $(1 / 2 / 3 / 4)^{* *}$ & $19 / 64 / 35 / 8$ & $36 / 102 / 32 / 10$ & $35 / 124 / 41 / 8$ & $38 / 67 / 41 / 9$ & 0.08 \\
\hline Season (October-April/May-September) & $96 / 30$ & $129 / 51$ & $157 / 51$ & $112 / 43$ & 0.73 \\
\hline
\end{tabular}

25(OH)D = 25-hydroxyvitamin D; BMI, body mass index; CASSS, Coronary Artery Surgery Study Score; HDL, high-density lipoprotein; LDL, low-density lipoprotein. ${ }^{\dagger}$ BMI class 1: <25; class 2: 25-30; class: $3>30 ; ~ \ddagger 0$, stable coronary artery disease; 1 , myocardial infarction; ${ }^{* *} 1:<10 \mathrm{ng} / \mathrm{mL}$ severe deficiency, $2: \geq 10$ to $<20 \mathrm{ng} / \mathrm{mL}$ moderate deficiency, $3: \geq 20$ to $<30 \mathrm{ng} / \mathrm{mL}$ mild deficiency, $4: \geq 30 \mathrm{ng} / \mathrm{mL}$ optimal.

Post hoc analyses in unequal subgroup populations revealed that CASSS 3 patients were significantly older than patients in all other CASSS groups ( $p<0.01$ for all compar- 
isons). Individual subgroups of patients with different CASSS scores were characterized by statistically significant differences in the prevalence of diabetes, hypertension, smoking, history of myocardial infarction, or the cause of the then ongoing hospitalization.

No significant differences were observed in $25(\mathrm{OH}) \mathrm{D}$ levels, BMI values, or triglyceride levels between patients across all CASSS groups. Neither could significant differences be observed in the prevalence of hyperlipidemia or the season of examination between individual CASSS groups.

Poisson distribution and multiple regression analysis were used to identify factors that significantly determined the CASSS in the male population. Factors/determinants in the analysis included serum 25(OH)D levels, age, BMI, smoking status, hypertension, concomitant diabetes, hyperlipidemia, history of myocardial infarction, cause of the then-current hospitalization, and season during the examination. Factors significantly determining the CASSS value included age $(p<0.05)$, cause of ongoing hospitalization $(p<0.001)$, smoking status $(p<0.05)$, and history of myocardial infarction $(p<0.001)$.

3.4. Male Patients without Significant Arterial Stenosis (CASSS 0) in Comparison with Patients with Significant Arterial Stenosis (CASSS 1-3)

The group of patients without significant changes within the coronary arteries (CASSS 0 ) presented with higher $25(\mathrm{OH}) \mathrm{D}$ levels than patients with single-, double-, or triple-vessel disease (CASSS 1, 2, or 3, respectively). Considering the above, we carried out further analyses with the study population divided into two subgroups: the CASSS 0 subgroup and the CASSS $1-3$ subgroup (Table 3 ).

Table 3. Characteristics of the examined group divided according to degree of coronary atherosclerosis (CASSS) into two subgroups.

\begin{tabular}{|c|c|c|c|}
\hline Variable & CASSS 0 & CASSS 1-3 & $p$ \\
\hline$N$ & 126 & 543 & \\
\hline Age (years] & $64 \pm 11$ & $65 \pm 11$ & 0.78 \\
\hline Body mass index $\left(\mathrm{kg} / \mathrm{m}^{2}\right)$ & $29 \pm 5$ & $28 \pm 5$ & $<0.01$ \\
\hline Body mass index class $(1 / 2 / 3)^{\dagger}$ & $30 / 45 / 47$ & $126 / 229 / 150$ & 0.13 \\
\hline Diabetes (No/Yes/Prediabetes) & $88 / 34 / 4$ & $330 / 191 / 22$ & 0.17 \\
\hline Total cholesterol (mg/dL) & $180 \pm 45$ & $170 \pm 46$ & $<0.05$ \\
\hline High-density lipoprotein (mg/dL) & $52 \pm 18$ & $45 \pm 13$ & $<0.001$ \\
\hline Low-density lipoprotein (mg/dL) & $104 \pm 38$ & $99 \pm 41$ & 0.28 \\
\hline Triglycerides (mg/dL) & $124 \pm 68$ & $131 \pm 75$ & 0.38 \\
\hline Hyperlipidemia (No/Yes) & $43 / 66$ & $222 / 282$ & 0.38 \\
\hline Hypertension (No/Yes) & $34 / 92$ & $90 / 453$ & $<0.01$ \\
\hline Smoking (No/Yes/Ex) & $88 / 26 / 12$ & $283 / 195 / 65$ & $<0.01$ \\
\hline History of myocardial infarction (No/Yes) & $115 / 11$ & $274 / 269$ & $<0.001$ \\
\hline Cause of hospitalization $(0 / 1)^{\ddagger}$ & $113 / 13$ & $276 / 264$ & $<0.001$ \\
\hline Level of 25-hydrokyvitamin D (ng/mL (range)) & $17(5-47)$ & $15(4-48)$ & $<0.01$ \\
\hline $25(\mathrm{OH}) \mathrm{D}$ level $(1 / 2 / 3 / 4) * *$ & $19 / 64 / 35 / 8$ & $109 / 293 / 114 / 27$ & 0.26 \\
\hline Season (October-April/May-September) & $96 / 30$ & $398 / 145$ & 0.51 \\
\hline
\end{tabular}

${ }^{\dagger}$ BMI class $1<25$; class 2 25-30; class $3>30$; $¥$, stable coronary artery disease; 1 , myocardial infarction

** 1 : $<10 \mathrm{ng} / \mathrm{mL}$ severe deficiency, $2: \geq 10$ to $<20 \mathrm{ng} / \mathrm{mL}$ moderate deficiency, $3: \geq 20$ to $<30 \mathrm{ng} / \mathrm{mL}$ mild deficiency, 4: $\geq 30 \mathrm{ng} / \mathrm{mL}$ optimal.

Statistically significant differences were observed between male patients with and without significant coronary stenosis with regard to serum $25(\mathrm{OH}) \mathrm{D}$, BMI values, total cholesterol levels, and HDL cholesterol levels. 
Statistically significant disproportions were observed between subgroups with regard to arterial hypertension status, smoking status, history of myocardial infarction, and cause of the then ongoing hospitalization.

Only 13 patients from the CASSS 0 subgroup were hospitalized for myocardial infarction; the remaining 113 subjects were hospitalized as a result of stable CAD. In addition, 11 patients in the CASSS 0 subgroup had a history of myocardial infarction. About half of the patients from the CASSS 1-3 subgroup were hospitalized for myocardial infarction; about half also had a history of myocardial infarction.

Factors significantly determining the CASSS value in the entire male subpopulation included age $(p<0.05)$, cause of the then-current hospitalization $(p<0.001)$, smoking status $(p<0.05)$, and history of myocardial infarction $(p<0.001)$. Among the CASSS $1-3$ subgroup of male patients, larger percentages of patients had arterial hypertension, were smokers, had a history of myocardial infarction, and reported to the department because of an acute coronary syndrome rather than stable CAD.

\subsection{Determinants of Serum 25(OH)D Levels in Male Cardiac Patients}

In the presented study group, significant determinants of serum $25(\mathrm{OH}) \mathrm{D}$ levels included the season of the year $(p<0.001)$ and hyperlipidemia $(p<0.01)$. Lower serum $25(\mathrm{OH}) \mathrm{D}$ levels were presented independently by patients with hyperlipidemia and those examined between October and April.

\subsection{Identifying the Group with the Lowest 25(OH)D Levels among Male Cardiac Patients}

Factors significantly determining the CASSS value included age $(p<0.05)$, cause of the then-ongoing hospitalization $(p<0.001)$, smoking status $(p<0.05)$, and history of myocardial infarction $(p<0.001)$. The lowest serum $25(\mathrm{OH}) \mathrm{D}$ levels were measured in elderly male cardiac patients hospitalized for an acute coronary syndrome, presenting with a history of myocardial infarction, positive smoking status, and diagnosis of hyperlipidemia, as well as undergoing examination between October and April.

\section{Discussion}

Cardiovascular diseases are ranked as the main cause of death in male patients aged over 65 years old, remaining the second in younger individuals [8]. Mortality rates due to CVD for males are higher than those for females [31]. To date, numerous studies suggested a correlation between low 25(OH)D levels and increased risk of death from cardiovascular causes was suggested $[32,33]$. The aim of our research was to assess the association between vitamin D serum levels the severity of CAD.

The findings of this research are consistent with the results of previous studies examining the association between serum 25(OH)D levels and CVD [12]. However, only a few studies thus far were conducted in male subpopulations only; most were carried out in mixed-sex populations [34-38]. In our study, male patients without significant coronary lesions (CASSS 0) presented with statistically higher serum vitamin D levels than patients with significant stenosis of coronary arteries (CASSS 1-3); however, the nominal difference was negligible. We showed that calcitriol serum levels were significantly lower in patients with a history of MI. Elderly patients with hyperlipidemia, actively smoking, hospitalized for an ACS, with a history of MI, were a subgroup presenting with the lowest $25(\mathrm{OH}) \mathrm{D}$ serum levels.

The impact of serum vitamin D level on the established cardiovascular risk factors (i.e., development of type 2 diabetes, metabolic syndrome) was repeatedly proven in the literature $[39,40]$.

Both nuclear vitamin D receptor (VDR) and the enzyme 25-hydroxyvitamin D3-1 $\alpha$ hydroxylase have been identified in various cells of the cardiovascular system, indicating a direct involvement of this hormone group in the initiation and progression of CVD [41]. Importantly, in patients with heart failure, atrial fibrillation, or coronary artery disease vitamin D deficiency was associated with a worse prognosis [42-44]. Moreover, hypovita- 
minosis D was proven to affect the established cardiovascular risk factors such as arterial hypertension [45], type 2 diabetes [44], or dyslipidemia [44]. Calcitriol inhibits the reninangiotensin-aldosterone system (RAAS) and the secretion of natriuretic peptides, thus having a hypotensive effect [46]. Activation of the VDR receptor has a protective effect on the excess of angiotensin II by inhibiting fibrosis and exerting anti-inflammatory and antiproliferative effects [47]. Mediated by cells of the immune system, calcitriol modulates the secretion of miR-106b-5p and inhibits the secretion of renin by the glomerular apparatus [48]. The impact of vitamin D on various stages of atherosclerosis is currently being a subject of some studies [13]. Previous studies demonstrated that vitamin D affects atherosclerotic plaque formation in numerous ways, including reducing the inflammatory response, inhibiting the NF-kB pathway [49], and suppressing the post-infarction scar formation [50]. Proper serum 25(OH)D level was proven to reduce the activity of the metalloproteinases, which degrade the fibrous cap of the atherosclerotic plaque [51]. In addition, vitamin $\mathrm{D}$ also inhibits the activity of vascular endothelial growth factors, preventing the formation of new vessels within an already formed plaque, thus contributing to its better stability [52]. After plaque rupture, vitamin D exerts an antithrombotic effect by increasing the production of thrombomodulin and reducing the expression of platelet tissue factors. Hence, it inhibits the adhesion of platelets to vascular endothelial cells [53]. This process may be a way of vitamin D contributing to the prevention of ACS.

A study based on an analysis of more than 1000 Polish patients confirmed the already reported low vitamin D levels in the Polish population [54,55], as well as the higher $25(\mathrm{OH}) \mathrm{D}$ levels in males than in females [26]. On the other hand, Verdoia emphasizes the importance of higher $25(\mathrm{OH}) \mathrm{D}$ levels noted in men, compared with women [56]. The results of that study provided a stimulus to expand the research and reassess how $25(\mathrm{OH}) \mathrm{D}$ levels affect the stage of CAD and incidence of $\mathrm{MI}$ in the entirely male cohort. The results of the above-mentioned studies stimulated us to evaluate the impact of $25(\mathrm{OH}) \mathrm{D}$ levels on the stage of coronary artery disease and the incidence of MI in an all-male cohort. The influence of vitamin D deficiency on episodes of MI in men is supported by several cohort studies [57,58]. Patients with 25(OH)D levels of $\leq 15 \mathrm{ng} / \mathrm{mL}$ were proven to have a more than 1.5-fold increase in the risk of adverse cardiovascular events (i.e., MI, angina pectoris, stroke, TIA, and heart failure) [57] and a twofold increase in the risk of ACS [58]. Moreover, low vitamin D levels and a history of MI were associated with a significant increase in the risk of further major adverse cardiovascular events (MACE), including reoccurrence of MI [37]. In addition, serum $25(\mathrm{OH})$ D levels above $7.3 \mathrm{ng} / \mathrm{mL}$ were associated with a $40 \%$ reduction in the risk of non-fatal MACE in patients with ACS.

To date, several studies examining vitamin $\mathrm{D}$ supplementation in patients with CVD have been conducted. Although none of the large cohort studies showed a favorable cardiovascular outcome, individual experiments have proven that six-month calcitriol supplementation significantly reduced the inflammation of coronary arteries [59] and declined SYNTAX score (67). However, poor bioavailability and large intervals between consecutive doses of cholecalciferol should be underlined as potentially resolvable issues [59]. Another possible mechanism by which vitamin D may affect the degree of progression of coronary disease is its effect on the metabolism of sex hormones. In the MESA study, lower 25(OH)D levels were found to be associated with lower sex-hormone-binding globulin concentrations and higher levels of free testosterone, which are important in the course of coronary artery disease [60].

Our research suffers from several limitations. The study group consisted of residents of only central Poland, most residing in urban areas. Expanding the study group to include residents of other provinces would facilitate the translation of the results to the entire Polish population. CAD staging was classified based on the results of coronary angiography using the CASSS. The classification of the severity of atherosclerosis based on the SYNTAX might change our results.

The results of the observational studies carried out so far have shown that the endocrine system of vitamin D, in addition to its documented effect on the skeletal system, 
exerts a wide spectrum of extra-skeletal activity [61,62]. In these studies, low vitamin $\mathrm{D}$ levels were found to be associated with an increased risk of cardiovascular diseases, including hypertension, congestive heart failure, as well as adverse cardiovascular events (MACE, heart attacks, and strokes). In a meta-analysis involving nearly 850,000 people, low serum $25(\mathrm{OH}) \mathrm{D}$ levels were associated with a 1.42 times higher risk of developing MACE, compared with patients with higher levels of vitamin D [63]. On the other hand, the results of randomized clinical trials (VITAL, ViDa, D2d), which included over 30,000 participants, showed that supplementation with vitamin $\mathrm{D}$ does not prevent cardiovascular events or the progression of type 2 diabetes [64-66]. It should be emphasized that the initial serum level of $25(\mathrm{OH}) \mathrm{D}$ in the respondents of the above-mentioned studies fluctuated above $50 \mathrm{nmol} / \mathrm{L}$, and post hoc analysis suggested some extra-skeletal benefits in the vitamin D deficiency group. The causal association between calcitriol and cardiovascular mortality continues to be the subject of much debate. New information was provided by the recently presented results of the non-linear MR analysis carried out at UK Biobank [67]. The authors of the cited study presented the association between the genetically predicted serum $25(\mathrm{OH}) \mathrm{D}$ levels and the risk of cardiovascular diseases to be L shaped. This research seems to confirm the results of observational and interventional studies and determines a specific range of vitamin D levels within which vitamin D supplementation may have a beneficial effect in short- and long-term observations. At the same time, it explains why supplementing people rich in vitamin D does not generate overall health benefits, and correction of a severe deficiency of this hormone may be necessary. At present, the opinions of scientists around the world unanimously recommend the correction of vitamin $\mathrm{D}(25(\mathrm{OH}) \mathrm{D}$ serum deficiency $<30 \mathrm{nmol} / \mathrm{L})$, and most scientific societies recommend a target level of $>50 \mathrm{nmol} / \mathrm{L}$ as optimal for bone health. In our opinion, vitamin $\mathrm{D}$ deficiency may also be an easily modifiable risk factor of the acute coronary syndrome in men, which should undoubtedly be the subject of further research. Perhaps, well-designed and conducted social campaigns in the field of proper exposure to solar radiation, food fortification, or pharmacological supplementation of vitamin D could considerably contribute to the prevention of CAD and its complications.

\section{Conclusions}

In conclusion, we demonstrated that male patients with a history of ACS and MI presented reduced serum calcitriol levels. Patients with advanced CAD presented with significantly lower levels of $25(\mathrm{OH}) \mathrm{D}$ than those without significant atherosclerotic lesions; however, the difference should be considered as clinically negligible. Further studies should be undertaken in specific subgroups, to assess the potential beneficial effects of vitamin $D$ supplementation in this group of patients.

Author Contributions: Conceptualization, E.A.D.; methodology, E.A.D.; formal analysis, E.A.D.; investigation, E.A.D.; resources, E.A.D.; data curation, E.A.D.; writing-original draft preparation, E.A.D., W.B.G., I.S., M.D. and P.J.; writing-review and editing, E.A.D., W.B.G., I.S., M.D. and P.J.; funding acquisition, E.A.D. All authors have read and agreed to the published version of the manuscript.

Funding: This research was partly supported by a statutory grant to the Cardiology Clinic of Physiotherapy Division from the Second Faculty of Medicine, Medical University of Warsaw, Poland Grant Number 2F5/PM2/16. The APC was funded by the Medical University of Warsaw.

Institutional Review Board Statement: The study was conducted according to the guidelines of the Declaration of Helsinki and approved by the Bioethical Committee of Medical University (KB/124/2014).

Informed Consent Statement: Informed consent was obtained from all subjects involved in the study.

Data Availability Statement: Data can be provided by the authors upon reasonable request.

Conflicts of Interest: William B. Grant receives funding from Bio-Tech Pharmacal, Inc. (Fayetteville, AR, USA). Other authors declare no conflict of interest. 


\section{References}

1. Crimmins, E.; Beltrán-Sánchez, H. Mortality and morbidity trends: Is there compression of morbidity? J. Gerontol. B Psychol. Sci. Soc. Sci. 2011, 66, 75-86. [CrossRef]

2. Kibele, E.U.; Jasilionis, D.; Shkolnikov, V.M. Widening socioeconomic differences in mortality among men aged 65 years and older in Germany. J. Epidemiol. Community Health 2013, 67, 453-457. [CrossRef]

3. Krumholz, H.M.; Nuti, S.V.; Downing, N.S.; Normand, S.L.; Wang, Y. Mortality, hospitalizations, and expenditures for the medicare population aged 65 years or older, 1999-2013. JAMA 2015, 314, 355-365. [CrossRef]

4. Leszko, M.; Zając-Lamparska, L.; Trempala, J. Aging in Poland. Gerontologist 2015, 55, 707-715. [CrossRef]

5. Maniecka-Bryła, I.; Bryła, M.; Bryła, P.; Pikala, M. The burden of premature mortality in Poland analysed with the use of standard expected years of life lost. BMC Public Health 2015, 15, 1-8. [CrossRef]

6. Liu, K.; Daviglus, M.L.; Loria, C.M.; Colangelo, L.A.; Spring, B.; Moller, A.C.; Lloyd-Jones, D.M. Healthy lifestyle through young adulthood and the presence of low cardiovascular disease risk profile in middle age: The Coronary Artery Risk Development in Young Adults (CARDIA) study. Circulation 2012, 125, 996-1004. [CrossRef]

7. Lozano, R.; Naghavi, M.; Foreman, K.; Lim, S.; Shibuya, K.; Aboyans, V.; Abraham, J.; Adair, T.; Aggarwal, R.; Ahn, S.Y.; et al. Global and regional mortality from 235 causes of death for 20 age groups in 1990 and 2010: A systematic analysis for the Global Burden of Disease Study 2010. Lancet 2012, 380, 2095-2128. [CrossRef]

8. Roth, G.A.; Mensah, G.A.; Johnson, C.O.; Addolorato, G.; Ammirati, E.; Baddour, L.M.; Barengo, N.C.; Beaton, A.Z.; Benjamin, E.J.; Benziger, C.P.; et al. Global Burden of Cardiovascular Diseases and Risk Factors, 1990-2019: Update from the GBD 2019 Study. J. Am. Coll. Cardiol. 2020, 76, 2982-3021. [CrossRef]

9. Suzuki, T.; Kohro, T.; Hayashi, D.; Yamazaki, T.; Nagai, R. Frequency and impact of lifestyle modification in patients with coronary artery disease: The Japanese Coronary Artery Disease (JCAD) study. Am. Heart J. 2012, 163, 268-273. [CrossRef]

10. Dehghan, M.; Mente, A.; Teo, K.K.; Gao, P.; Sleight, P.; Dagenais, G.; Avezum, A.; Probstfield, J.L.; Dans, T.; Yusuf, S.; et al. Relationship between healthy diet and risk of cardiovascular disease among patients on drug therapies for secondary prevention: A prospective cohort study of 31546 high risk individuals from 40 countries. Circulation 2012, 126, 2705-2712. [CrossRef]

11. Holick, M.F. Vitamin D deficiency. NEJM 2007, 357, 266-281. [CrossRef]

12. Michos, E.D.; Cainzos-Achirica, M.; Heravi, A.S.; Appel, L.J. Vitamin D, Calcium Supplements, and Implications for Cardiovascular Health: JACC Focus Seminar. J. Am. Coll. Cardiol. 2021, 77, 437-449. [CrossRef]

13. Kassi, E.; Adamopoulos, C.; Basdra, E.K.; Papavassiliou, A.G. Role of vitamin D in atherosclerosis. Circulation 2013, 128, $2517-2531$. [CrossRef]

14. Al Mheid, I.; Quyyumi, A.A. Vitamin D and Cardiovascular Disease: Controversy Unresolved. J. Am. Coll. Cardiol. 2017, 70, 89-100. [CrossRef]

15. Somjen, D.; Weisman, Y.; Kohen, F.; Gayer, B.; Limor, R.; Sharon, O.; Jaccard, N.; Knoll, E.; Stern, N. 25-hydroxyvitamin D3-1alphahydroxylase is expressed in human vascular smooth muscle cells and is upregulated by parathyroid hormone and estrogenic compounds. Circulation 2005, 111, 1666-1671. [CrossRef]

16. Zehnder, D.; Bland, R.; Chana, R.S.; Wheeler, D.C.; Howie, A.J.; Williams, M.C.; Stewart, P.M.; Hewison, M. Synthesis of 1,25-dihydroxyvitamin $\mathrm{D}(3)$ by human endothelial cells is regulated by inflammatory cytokines: A novel autocrine determinant of vascular cell adhesion. J. Am. Soc. Nephrol. 2002, 13, 621-629.

17. Li, Y.C. 1,25-Dihydroxyvitamin $\mathrm{D}(3)$ is a negative endocrine regulator of the renin-angiotensin system. J. Clin. Investig. 2002, 110, 229-238. [CrossRef]

18. Zhou, C.; Lu, F.; Cao, K.; Xu, D.; Goltzman, D.; Miao, D. Calcium-independent and 1,25(OH)2D3-dependent regulation of the renin-angiotensin system in 1alpha-hydroxylase knockout mice. Kidney Int. 2008, 74, 170-179. [CrossRef]

19. Chen, S.; Law, C.S.; Grigsby, C.L.; Olsen, K.; Hong, T.T.; Zhang, Y.; Yeghiazarians, Y.; Gardner, D.G. Cardiomyocyte-specific deletion of the vitamin D receptor gene results in cardiac hypertrophy. Circulation 2011, 124, 1838-1847. [CrossRef]

20. Izzo, M.; Carrizzo, A.; Izzo, C.; Cappello, E.; Cecere, D.; Ciccarelli, M.; Iannece, P.; Damato, A.; Vecchione, C.; Pompeo, F. Vitamin D: Not Just Bone Metabolism but a Key Player in Cardiovascular Diseases. Life 2021, 11, 452. [CrossRef]

21. Spiro, A.; Buttriss, J.L. Vitamin D: An overview of vitamin D status and intake in Europe. Nutr. Bull. 2014, 39, 322-350. [CrossRef]

22. Lee, J.H.; Gadi, R.; Spertus, J.A.; Tang, F.; O'Keefe, J.H. Prevalence of vitamin d deficiency in patients with acute myocardial infarction. Am. J. Cardiol. 2011, 107, 1636-1638. [CrossRef]

23. Pludowski, P.; Holick, M.F.; Pilz, S.; Wagner, C.L.; Hollis, B.W.; Grant, W.B.; Shoenfeld, Y.; Lerchbaum, E.; Llewellyn, D.J.; Kienreich, K.; et al. Vitamin D effects on musculoskeletal health, immunity, autoimmunity, cardiovascular disease, cancer, fertility, pregnancy, dementia and mortality-a review of recent evidence. Autoimmun. Rev. 2013, 12, 976-989. [CrossRef]

24. Dziedzic, E.A.; Gąsior, J.S.; Pawłowski, M.; Dabrowski, M. Association of Vitamin D Deficiency and Degree of Coronary Artery Disease in Cardiac Patients with Type 2 Diabetes. J. Diabetes Res. 2017, 2017, 3929075. [CrossRef]

25. Dziedzic, E.A.; Gąsior, J.S.; Pawłowski, M.; Wodejko-Kucharska, B.; Saniewski, T.; Marcisz, A.; Dąbrowski, M.J. Vitamin D level is associated with severity of coronary artery atherosclerosis and incidence of acute coronary syndromes in non-diabetic cardiac patients. Arch. Med. Sci. 2019, 15, 359-368. [CrossRef]

26. Dziedzic, E.A.; Przychodzeń, S.; Dabrowski, M. The effects of vitamin D on severity of coronary artery atherosclerosis and lipid profile of cardiac patients. Arch. Med. Sci. 2016, 12, 1199-1206. [CrossRef] 
27. Dziedzic, E.A.; Gasior, J.S.; Saniewski, T.; Dąbrowski, M. Vitamin D deficiency among Polish patients with angiographically confirmed coronary heart disease. Pol. Tow. Lek. 2021, 49, 278-282.

28. Cobas E411 Vitamin D Total Reagent Insert (07464215190V2.0), Roche Diagnostics. Available online: http:/ /labogids.sintmaria. be/sites/default/files/files/vit._d_total_ii_2017-11_v2.pdf (accessed on 29 December 2021).

29. Płudowski, P.; Karczmarewicz, E.; Bayer, M.; Carter, G.; Chlebna-Sokół, D.; Czech-Kowalska, J.; Dębski, R.; Decsi, T.; Dobrzańska, A.; Franek, E.; et al. Practical guidelines for the supplementation of vitamin D and the treatment of deficits in Central Europe -Recommended vitamin D intakes in the general population and groups at risk of vitamin D deficiency. Endokrynol. Pol. 2013, 64, 319-327. [CrossRef]

30. Ringqvist, I.; Fisher, L.D.; Mock, M.; Davis, K.B.; Wedel, H.; Chaitman, B.R.; Passamani, E.; Russell, R.O., Jr.; Alderman, E.L.; Kouchoukas, N.T.; et al. Prognostic value of angiographic indices of coronary artery disease from the Coronary Artery Surgery Study (CASS). J. Clin. Investig. 1983, 71, 1854-1866. [CrossRef]

31. Gao, Z.; Chen, Z.; Sun, A.; Deng, X. Gender differences in cardiovascular disease. Med. Nov. Technol. Devices $2019,4,100025$. [CrossRef]

32. Szulc, P.; Claustrat, B.; Delmas, P.D. Serum concentrations of 17beta-E2 and 25-hydroxycholecalciferol (25OHD) in relation to all-cause mortality in older men-the MINOS study. Clin. Endocrinol. (Oxf.) 2009, 71, 594-602. [CrossRef]

33. Johansson, H.; Odén, A.; Kanis, J.; McCloskey, E.; Lorentzon, M.; Ljunggren, Ö.; Karlsson, M.K.; Thorsby, P.M.; Tivesten, Å.; Barrett-Connor, E.; et al. Low serum vitamin D is associated with increased mortality in elderly men: MrOS Sweden. Osteoporos. Int. 2012, 23, 991-999. [CrossRef]

34. Scragg, R.; Jackson, R.; Holdaway, I.M.; Lim, T.; Beaglehole, R. Myocardial-infarction is inversely associated with plasma 25-hydroxyvitamin-D3 levels—a community based study. Int. J. Epidemiol. 1990, 19, 559-563. [CrossRef]

35. Ng, L.L.; Sandhu, J.K.; Squire, I.B.; Davies, J.E.; Jones, D.J. Vitamin D and prognosis in acute myocardial infarction. Int. J. Cardiol. 2013, 168, 2341-2346. [CrossRef]

36. De Metrio, M.; Milazzo, V.; Rubino, M.; Cabiati, A.; Moltrasio, M.; Marana, I.; Campodonico, J.; Cosentino, N.; Veglia, F.; Bonomi, A.; et al. Vitamin D plasma levels and in-hospital and 1-year outcomes in acute coronary syndromes: A prospective study. Medicine 2015, 94, e857. [CrossRef]

37. Aleksova, A.; Belfiore, R.; Carriere, C.; Kassem, S.; La Carrubba, S.; Barbati, G.; Sinagra, G. Vitamin D deficiency in patients with acute myocardial infarction: An italian single-center study. Int. J. Vitam. Nutr. Res. 2015, 85, 23-30. [CrossRef]

38. Correia, L.C.; Sodré, F.; Garcia, G.; Sabino, M.; Brito, M.; Kalil, F.; Barreto, B.; Lima, J.C.; Noya-Rabelo, M.M. Relation of severe deficiency of vitamin D to cardiovascular mortality during acute coronary syndromes. Am. J. Cardiol. 2013, 111, $324-327$. [CrossRef]

39. Gagnon, C.; Lu, Z.X.; Magliano, D.J.; Dunstan, D.W.; Shaw, J.E.; Zimmet, P.Z.; Sikaris, K.; Ebeling, P.R.; Daly, R.M. Low serum 25-hydroxyvitamin $\mathrm{D}$ is associated with increased risk of the development of the metabolic syndrome at five years: Results from a national, population-based prospective study (The Australian Diabetes, Obesity and Lifestyle Study: AusDiab). J. Clin. Endocrinol. Metab. 2012, 97, 1953-1961. [CrossRef]

40. Pittas, A.G.; Lau, J.; Hu, F.B.; Dawson-Hughes, B. The role of vitamin D and calcium in type 2 diabetes. A systematic review and meta-analysis. J. Clin. Endocrinol. Metab. 2007, 92, 2017-2029. [CrossRef]

41. Cosentino, N.; Campodonico, J.; Milazzo, V.; De Metrio, M.; Brambilla, M.; Camera, M.; Marenzi, G. Vitamin D and Cardiovascular Disease: Current Evidence and Future Perspectives. Nutrients 2021, 13, 3603. [CrossRef]

42. Mensah, G.A.; Wei, G.S.; Sorlie, P.D.; Fine, L.J.; Rosenberg, Y.; Kaufmann, P.G.; Mussolino, M.E.; Hsu, L.L.; Addou, E.; Engelgau, M.M.; et al. Decline in Cardiovascular Mortality: Possible Causes and Implications. Circ. Res. 2017, 120, 366-380. [CrossRef] [PubMed]

43. Norman, P.E.; Powell, J.T. Vitamin D and cardiovascular disease. Circ. Res. 2014, 114, 379-393. [CrossRef]

44. Zittermann, A. Vitamin D Status, Supplementation and Cardiovascular Disease. Anticancer Res. 2018, 38, 1179-1186.

45. Karadeniz, Y.; Özpamuk-Karadeniz, F.; Ahbab, S.; Ataoğlu, E.; Can, G. Vitamin D Deficiency Is a Potential Risk for Blood Pressure Elevation and the Development of Hypertension. Medicina 2021, 57, 1297. [CrossRef]

46. Pilz, S.; Tomaschitz, A. Role of vitamin D in arterial hypertension. Expert Rev. Cardiovasc. Ther. 2010, 8, 1599-1608. [CrossRef]

47. Cui, C.; Xu, P.; Li, G.; Qiao, Y.; Han, W.; Geng, C.; Liao, D.; Yang, M.; Chen, D.; Jiang, P. Vitamin D receptor activation regulates microglia polarization and oxidative stress in spontaneously hypertensive rats and angiotensin II-exposed microglial cells: Role of renin-angiotensin system. Redox Biol. 2019, 26, 101295. [CrossRef]

48. Oh, J.; Matkovich, S.J.; Riek, A.E.; Bindom, S.M.; Shao, J.S.; Head, R.D.; Barve, R.A.; Sands, M.S.; Carmeliet, G.; Osei-Owusu, P.; et al. Macrophage secretion of miR-106b-5p causes renin-dependent hypertension. Nat. Commun. 2020, 11, 4798. [CrossRef]

49. Chen, S.; Swier, V.J.; Boosani, C.S.; Radwan, M.M.; Agrawal, D.K. Vitamin D deficiency accelerates coronary artery disease progression in swine. Arterioscler. Thromb. Vasc. Biol. 2016, 36, 1651-1659. [CrossRef]

50. Ahmad, M.I.; Chevli, P.A.; Li, Y.; Soliman, E.Z. Vitamin D deficiency and electrocardiographic subclinical myocardial injury: Results from national health and nutrition examination survey-iii. Clin. Cardiol. 2018, 41, 1468-1473. [CrossRef]

51. Bahar-Shany, K.; Ravid, A.; Koren, R. Upregulation of MMP-9 production by TNFalpha in keratinocytes and its attenuation by vitamin D. J. Cell. Physiol. 2010, 222, 729-737.

52. Mantell, D.J.; Owens, P.E.; Bundred, N.J.; Mawer, E.B.; Canfield, A.E. 1 Alpha,25-dihydroxyvitamin D (3) inhibits angiogenesis in vitro and in vivo. Circ. Res. 2000, 87, 214-220. [CrossRef] [PubMed] 
53. Koyama, T.; Shibakura, M.; Ohsawa, M.; Kamiyama, R.; Hirosawa, S. Anticoagulant effects of 1alpha,25dihydroxyvitamin D3 on human myelogenous leukemia cells and monocytes. Blood 1998, 92, 160-167. [CrossRef] [PubMed]

54. Płudowski, P.; Ducki, C.; Konstantynowicz, J.; Jaworski, M. Vitamin D status in Poland. Pol. Arch. Med. Wewn 2016, 126, 530-539. [CrossRef] [PubMed]

55. Pludowski, P.; Grant, W.B.; Bhattoa, H.P.; Bayer, M.; Povoroznyuk, V.; Rudenka, E.; Ramanau, H.; Varbiro, S.; Rudenka, A.; Karczmarewicz, E.; et al. Vitamin D status in Central Europe. Int. J. Endocrinol. 2014, 2014, 589587. [CrossRef]

56. Verdoia, M.; Schaffer, A.; Barbieri, L.; Di Giovine, G.; Marino, P.; Suryapranata, H.; De Luca, G.; Novara Atherosclerosis Study Group (NAS). Impact of gender difference on vitamin D status and its relationship with the extent of coronary artery disease. Nutr. Metab. Cardiovasc. Dis. 2015, 25, 464-470. [CrossRef]

57. Wang, T.J.; Pencina, M.J.; Booth, S.L.; Jacques, P.F.; Ingelsson, E.; Lanier, K.; Benjamin, E.J.; D'Agostino, R.B.; Wolf, M.; Vasan, R.S. Vitamin D deficiency and risk of cardiovascular disease. Circulation 2008, 117, 503-511. [CrossRef]

58. Giovannucci, E.; Liu, Y.; Hollis, B.W.; Rimm, E.B. 25-hydroxyvitamin d and risk of myocardial infarction in men: A prospective study. Arch. Intern Med. 2008, 168, 1174-1180. [CrossRef]

59. Dalle Carbonare, L.; Valenti, M.T.; Del Forno, F.; Caneva, E.; Pietrobelli, A. Vitamin D: Daily vs. Monthly use in children and elderly-what is going on? Nutrients 2017, 9, 652. [CrossRef]

60. Zhao, D.; Ouyang, P.; de Boer, I.H.; Lutsey, P.L.; Farag, Y.M.; Guallar, E.; Siscovick, D.S.; Post, W.S.; Kalyani, R.R.; Billups, K.L.; et al. Serum vitamin D and sex hormones levels in men and women: The Multi-Ethnic Study of Atherosclerosis (MESA). Maturitas 2017, 96, 95-102. [CrossRef]

61. Bouillon, R.; Marcocci, C.; Carmeliet, G.; Bikle, D.; White, J.H.; Dawson-Hughes, B.; Lips, P.; Munns, C.F.; Lazaretti-Castro, M.; Giustina, A.; et al. Skeletal and Extraskeletal Actions of Vitamin D: Current Evidence and Outstanding Questions. Endocr. Rev. 2019, 40, 1109-1151. [CrossRef]

62. Bouillon, R.; Manousaki, D.; Rosen, C.; Trajanoska, K.; Rivadeneira, F.; Richards, J.B. The health effects of vitamin D supplementation: Evidence from human studies. Nat. Rev. Endocrinol. 2022, 18, 96-110. [CrossRef]

63. Manson, J.E.; Cook, N.R.; Lee, I.M.; Christen, W.; Bassuk, S.S.; Mora, S.; Gibson, H.; Gordon, D.; Copeland, T.; D’Agostino, D.; et al. Vitamin D Supplements and Prevention of Cancer and Cardiovascular Disease. N. Engl. J. Med. 2019, 380, 33-44. [CrossRef]

64. Scragg, R.; Khaw, K.T.; Toop, L.; Sluyter, J.; Lawes, C.M.M.; Waayer, D.; Giovannucci, E.; Camargo, C.A., Jr. Monthly High-Dose Vitamin D Supplementation and Cancer Risk: A Post Hoc Analysis of the Vitamin D Assessment Randomized Clinical Trial. JAMA Oncol. 2018, 4, e182178. [CrossRef]

65. Pittas, A.G.; Dawson-Hughes, B.; Sheehan, P.; Ware, J.H.; Knowler, W.C.; Aroda, V.R.; Brodsky, I.; Ceglia, L.; Chadha, C.; Chatterjee, R.; et al. Vitamin D supplementation and prevention of type 2 diabetes. N. Engl. J. Med. 2019, 381, 520-530. [CrossRef]

66. Barbarawi, M.; Kheiri, B.; Zayed, Y.; Barbarawi, O.; Dhillon, H.; Swaid, B.; Yelangi, A.; Sundus, S.; Bachuwa, G.; Alkotob, M.L.; et al. Vitamin D Supplementation and Cardiovascular Disease Risks in More Than 83,000 Individuals in 21 Randomized Clinical Trials: A Meta-analysis. JAMA Cardiol. 2019, 4, 765-776. [CrossRef]

67. Zhou, A.; Selvanayagam, J.B.; Hyppönen, E. Non-linear Mendelian randomization analyses support a role for vitamin D deficiency in cardiovascular disease risk. Eur. Heart J. 2021, 11, 809. [CrossRef] 